\title{
Communication
}

[Comunicação]

\section{A comparison of two agar gel immunodiffusion methods and a complement fixation test for serologic diagnosis of Brucella ovis infection in experimentally infected rams}

[Comparação entre dois métodos de imunodifusão em gel de Agar e um método de fixação de complemento para o diagnóstico sorológico da infecção por Brucella ovis em carneiros experimentalmente infectados]

M.N. Xavier ${ }^{1}$, F.M. Sant'Anna ${ }^{1}$, T.M.A. Silva ${ }^{1}$, E.A. Costa ${ }^{1}$, V.S. Moustacas ${ }^{1}$, F.A. Merlo ${ }^{1}$, C.A. Carvalho Júniorr', M.G. Dasso², L.A. Mathias ${ }^{3}$, A.M.G. Gouveia ${ }^{1}$, A.P. Lage ${ }^{1}$, R.L. Santos ${ }^{1 *}$

${ }^{1}$ Escola de Veterinária - UFMG

Av. Antônio Carlos, 6627

31270-901 - Belo Horizonte, MG

${ }^{2}$ Laboratório de Brucelose, Instituto de Pesquisas Veterinárias Desidério Finamor - IPVDF - Eldorado do Sul, RS

${ }^{3}$ Faculdade de Ciências Agrárias e Veterinária - Universidade Estadual Paulista - Jaboticabal, SP

Ovine brucellosis due to Brucella ovis infection is worldwide considered one of the most important infectious diseases of sheep in raising areas. The disease is caused by a Gram-negative bacteria of the genus Brucella, which are facultative intracellular coccobacilli that belong to the a2-Proteobacteriacea family (Xavier et al., 2009). Clinical signs of the infection consist of chronic epididymitis and infertility in rams (Xavier et al., 2009) and, occasionally, abortion in ewes and birth of weak lambs (Molello et al., 1963). In Brazil, a seroprevalence of $13.4 \%$ (ranging from 6.9 to $50 \%$ ) positive sheep flocks has been reported in the state of Rio Grande do Sul, whereas a seroprevalence of $5.57 \%$ has been reported in the Northeastern part of the country (reviewed by Xavier et al., 2009).

Serologic diagnosis of $B$. ovis infection may be achieved through a wide range of tests, including complement fixation (CF) (Alton et al., 1988), agar gel immunodiffusion (AGID) (Myers and Siniuk, 1970), and the enzyme immunoassays (ELISA) (Gall et al., 2003) are the most commonly used for routine diagnosis of the disease. Importantly, $\mathrm{CF}$ has been applied as the standard serological test in $B$. ovis eradication programs worldwide. However, $\mathrm{CF}$ is also

Recebido em 27 de fevereiro de 2011

Aceito em 21 de março de 2011

* Autor para correspondência (corresponding author)

E-mail: rsantos@vet.ufmg.br considered a laborious technique, which is time consuming and requires well trained personnel (Alton et al., 1988). Conversely, AGID is considered highly sensitive, and has a simple and low cost execution. Consequently, AGID has been used in replacement of $\mathrm{CF}$ for the diagnosis of B. ovis infection in several countries, including Brazil (Manual..., 2009). The aim of this work was to evaluate three serological tests using commercially available antigens for the diagnosis of $B$. ovis infection in experimentally infected rams.

A total of 181 ovine serum samples were used in this study, being 117 from experimentally infected rams. The remaining 64 samples included nine samples obtained from the experimentally infected rams prior to inoculation, and the other 55 serum samples were obtained from sheep of different ages belonging to a B. ovis-free flock, which had no history of epididymitis or infertility, and was located in Belo Horizonte, Brazil. Nine 1 to 3-year-old cross-breed rams were experimentally infected as previously described (Xavier et al., 2010). Blood samples were collected from the jugular vein, serum was separated, and stored at $-20^{\circ} \mathrm{C}$. This experiment was approved by the Universidade Federal de Minas Gerais Committee for Experimental Animal Use (CETEA, protocol 02/2007). 
AGID was performed using two commercially available antigens: (i) an antigen manufactured by the Instituto de Tecnologia do Paraná (TECPAR, Brazil), containing B. ovis (strain REO 198) lipopolysaccharide and cellular wall protein extracts; and (ii) an antigen manufactured by the Instituto de Pesquisas Veterinárias Desidério Finamor (IPVDF, Brazil), containing soluble extracts from log phase heat-inactivated B. ovis strain REO 198. AGID test was performed as previously described (Marín et al., 1989). Briefly, $4.6 \mathrm{~mL}$ of $1.1 \%$ agarose gel (Invitrogen, Brazil) diluted in $0.1 \mathrm{M}$ borate buffer pH 8.6 was placed onto a clean microscope slide. A central well of $5.3 \mathrm{~mm}$ and six outer wells of $4.0 \mathrm{~mm}$ in diameter were cut, with distance between the central well and outer wells of $3.0 \mathrm{~mm}$. Two diametrically opposed wells were filled with $30 \mu \mathrm{L}$ positive control serum provided by each kit and the other four wells with $30 \mu \mathrm{L}$ of test serum. The central well was filled with $30 \mu \mathrm{L}$ of antigen (either TECPAR or IPVDF). The slides were incubated for $72 \mathrm{~h}$ at $4^{\circ} \mathrm{C}$ in a humid atmosphere. Reaction was visualized with indirect light. Positive sera developed sharp precipitation lines. Any sera giving a line of identity with the positive control lines were considered positive.

$\mathrm{CF}$ was performed in microtitre plates as described by Alton et al. (1988). Complement, antigen, and hemolysin dilutions were determined by titration (Alton et al., 1988). IPVDF antigen was used in a dilution of 1:60. The test sera and positive or negative controls were first diluted at 1:2 with Triethanolamine buffer (TBS; $0.05 \%$ gelatin, $0.15 \mathrm{M} \mathrm{CaCl}_{2}, 0.5 \mathrm{M}$ $\mathrm{MgCl}_{2}, 0.12 \mathrm{M} \mathrm{NaCl}, 0.28 \%$ triethanolamine, and $0.017 \mathrm{M} \mathrm{HCl}$ ) in glass tubes and inactivated at $60^{\circ} \mathrm{C}$ for $30 \mathrm{~min}$. Sera were distributed in the microplates in double dilutions from 1:2 to $1: 128$ in Triethanolamine buffer, with a final volume of $25 \mu \mathrm{L}$ in each well. After dilution, $25 \mu \mathrm{L}$ of antigen and $25 \mu \mathrm{L}$ of preserved complement diluted to contain 2.5 minimal hemolytic doses were added to each well, with $25 \mu \mathrm{L}$ of TBS replacing the antigen in serum control. The microplates were incubated at $37^{\circ} \mathrm{C}$ for 30 minutes. Then, an aliquot of $25 \mu \mathrm{L}$ of a $2 \%$ suspension of sheep red blood cells sensitized with hemolysin, was added to each well and again incubated at $37^{\circ} \mathrm{C}$ for $30 \mathrm{~min}$.
After centrifugation at $1,500 \mathrm{xg}$ for $20 \mathrm{~min}$, results were visually read at each dilution as 0 (complete hemolysis), 1 (75\% hemolysis), $2 \quad(50 \%$ hemolysis), 3 (25\% hemolysis), or 4 (no hemolysis). The titre was the reciprocal of the highest dilution of serum in which there was less than $75 \%$ hemolysis. Serum samples that presented titre $\geq 4$ were considered to be positive for B. ovis infection (Alton et al., 1988). Geometric means of $\mathrm{CF}$ titers considering all experimentally infected rams at a given time point during infection were calculated.

Frequencies of positive sera samples by the three serological methods were compared by Fisher's exact test using the GraphPad InStat software, version 3.05 (GraphPad InStat software, Inc., USA) with a 95\% confidence level. The sensitivity and specificity were assessed according to Henken et al. (1997), with GraphPad software, version 3.05 (InStat Inc., USA) with $95 \%$ confidence level. Proportion of agreement between diagnosis methods was assessed by Kappa test, with Minitab 15 software (Global Tech, Brazil) with 95\% confidence level.

The three methods evaluated in this study detected antibodies against B. ovis in $55.6 \%$ (5/9), $77.8 \%$ (7/9), and $77.8 \%$ (7/9) of experimentally infected rams as early as 15 days post-infection (dpi), for AGID-TECPAR, AGIDIPVDF, and $\mathrm{CF}$, respectively (Figure 1). The highest percentages of positive rams were observed from 30 to $60 \mathrm{dpi}$ for all serological tests, with $100 \%$ (9/9) of positivity by CF from 30 to 45 dpi, whereas both AGID tests detected antibodies against B. ovis in up to $88.9 \%(8 / 9)$ of the rams at the same time points (Figure 1).

The average serological titers obtained by the CF method also reached the highest values from 30 to $60 \mathrm{dpi}$, but positive titers $(\geq 4)$ were maintained only until 75 dpi (Figure 2). Frequency of positive rams as assessed by both AGID methods oscillated from 60 dpi until the end of the study period (Figure 1), with a tendency to a decreasing positive frequency over the time course of infection. Conversely, the frequency of detection of serological positive rams by the $\mathrm{CF}$ method showed a tendency of constant drop throughout the course of the experimental infection (Figure 1). Indeed, the average serological titers obtained by $\mathrm{CF}$ followed this same pattern (Figure 2). 


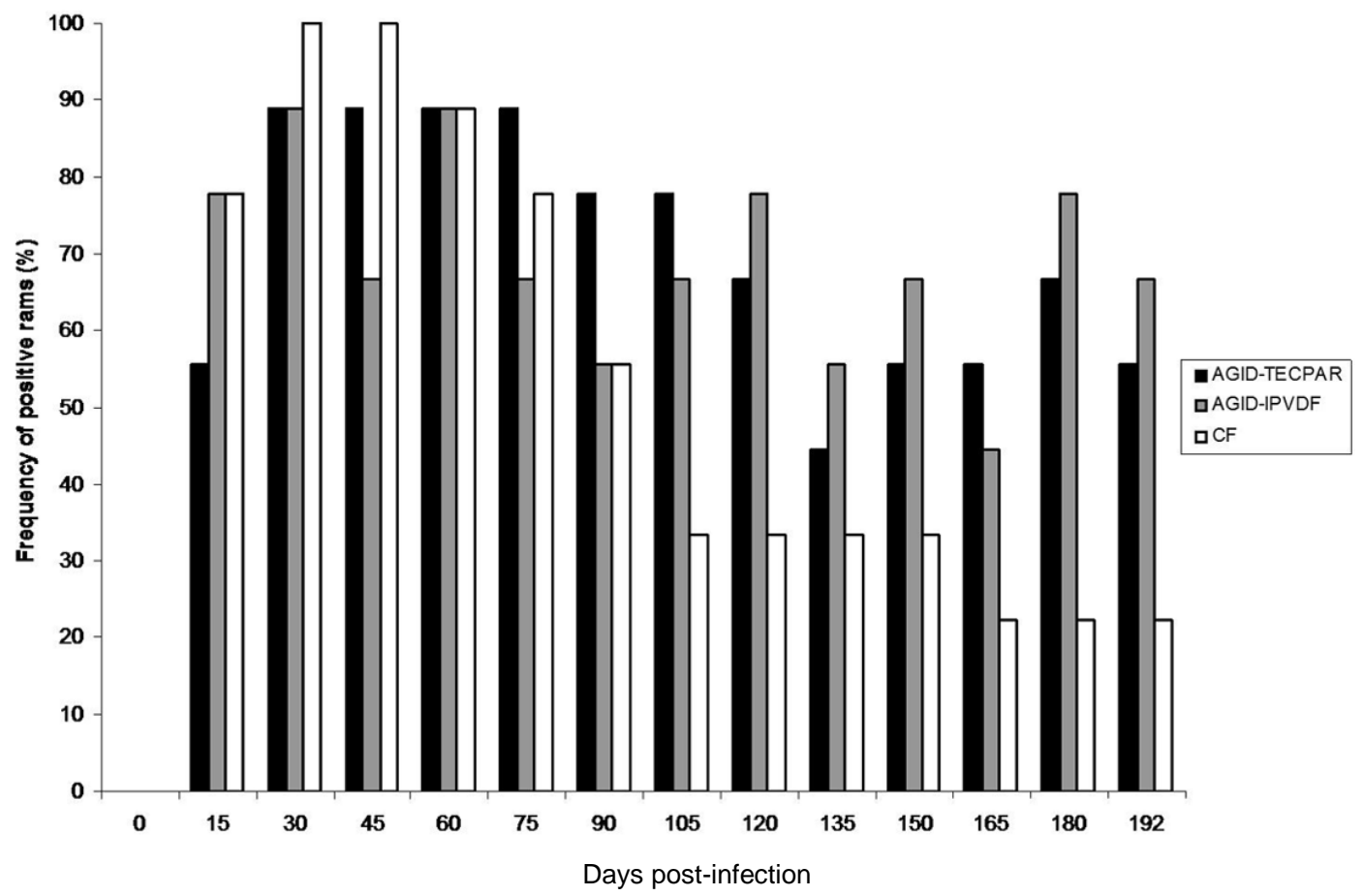

Figure 1. Frequency (\%) of Brucella ovis serological positive rams by agar gel immunodiffusion (AGID) with the TECPAR antigen (AGID-TECPAR) or the Desidério Finamor antigen (AGID-IPVDF), and by complement fixation (CF) throughout the course of experimental infection (up to 192 days post infection).

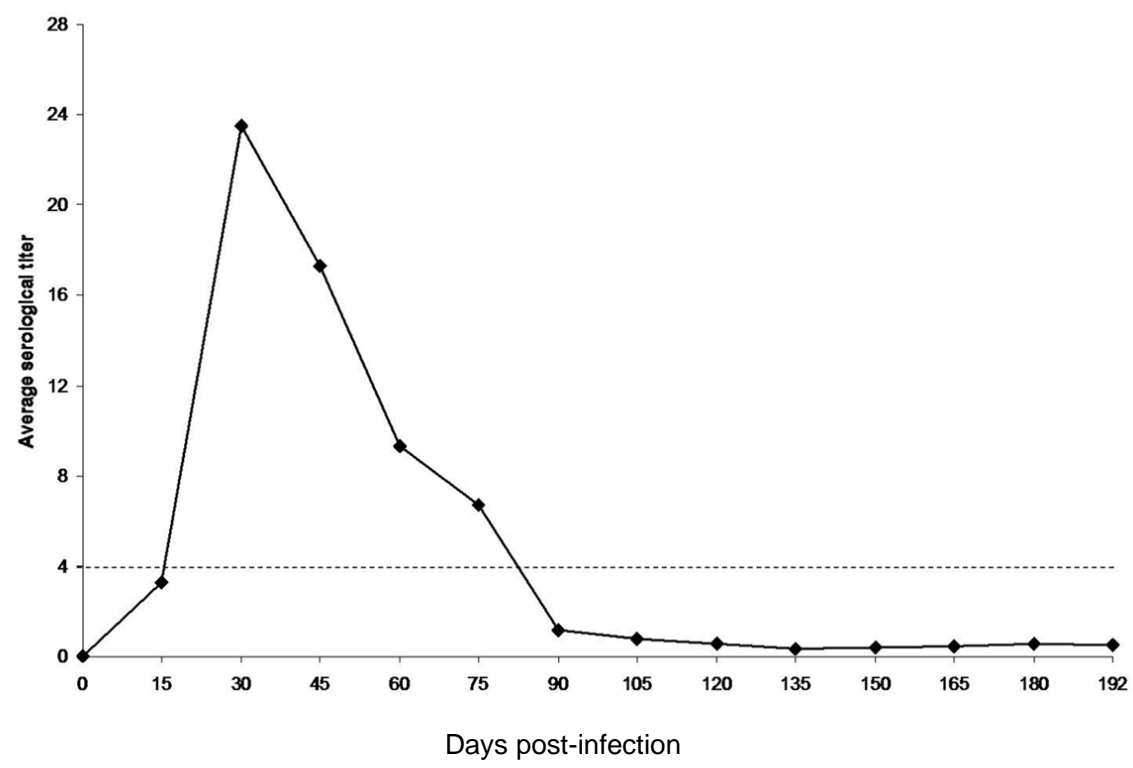

Figure 2. Average serological titers of antibodies against Brucella ovis as assessed by complement fixation $(\mathrm{CF})$ in sera from experimentally infected rams throughout 192 days of experimental infection. The dotted line represents the cutting point of positivity (titer $\geq 4$ ). 
All 117 sera samples obtained from experimentally infected rams were considered as truly positive samples, since all nine rams were subjected to a $B$. ovis high challenge. Conversely, the remaining 64 sera samples were considered as truly negative samples, since they were obtained from rams during the preinoculation period $(\mathrm{n}=9)$ or from a $B$. ovis-free flock $(n=55)$. The overall percentages of positive samples as assessed by AGID were $45.3 \%$ (82/181) and $44.7 \%$ (81/181) when considering AGID-TECPAR and AGID-IPVDF, respectively, which were similar $(\mathrm{P}>0.05)$. However, the overall frequency of positivity by CF was $33.7 \%$ (61/181), which was statistically lower than the percentage obtained by both AGID tests $(\mathrm{P}>0.05)$.

Sensitivity results are shown in Table 1 . In order to achieve a more precise evaluation of sensitivity, serum samples from experimentally infected rams were grouped into monthly periods post-infection, from one to six months, with a $\mathrm{n}=18$ for each period, with exception of six months post-infection (mpi), with $n=27$. The AGID-TECPAR method had the highest sensitivity value of $88.8 \%$ at $2 \mathrm{mpi}$, followed by statistically similar sensitivity values until $4 \mathrm{mpi}$. However, in the last $2 \mathrm{mpi}$ (i.e. $5^{\text {th }}$ and $6^{\text {th }} \mathrm{mpi}$ ) the sensitivity of this method decreased significantly $(\mathrm{P}<0.05)$, reaching values as low as $50 \%$. Conversely, AGID-IPVDF maintained statistically similar sensitivity values throughout the time course of experimental infection $(\mathrm{P}>0.05)$.

CF had the highest sensitivity values during the first $2 \mathrm{mpi}$, reaching $88.8 \%$ and $94.4 \%$ at the $1^{\text {st }}$ and $2^{\text {nd }}$ months, respectively. However, CF sensitivity values decreased significantly beginning at the $4^{\text {th }} \mathrm{mpi}(\mathrm{P}<0.05)$, reaching values as low as $22.2 \%$ in the last mpi. When comparing all three serological tests, statistically significant differences were observed beginning at the $4^{\text {th }} \mathrm{mpi}$, when $\mathrm{CF}$ had lower sensitivity (P>0.05) when compared to AGID. Both AGID methods had statistically similar sensitivity throughout the course of experimental infection. Indeed, the same pattern was observed when sensitivity results considering all six months of infection were evaluated together, but FC had a significantly lower sensitivity $(\mathrm{P}>0.05)$. In this case, sensitivity values were of $70.1 \%, 69.2 \%$, and $53.8 \%$ for AGID-TECPAR, AGID-IPVDF, and $\mathrm{CF}$ methods, respectively. All 64 samples considered to be truly negative for $B$. ovis infection had negative results in all three serological tests evaluated (data not shown). Therefore, both AGID methods as well as the CF test had $100 \%$ specificity.

Table 1. Sensitivity of agar gel immunodiffusion (AGID) with the TECPAR antigen (AGID-TECPAR) or the Desidério Finamor antigen (AGID-IPVDF) and complement fixation (CF) for detection of antibodies against Brucella ovis in ovine serum samples throughout six months of experimental infection

\begin{tabular}{cccccccc}
\hline \multirow{2}{*}{ Method } & \multicolumn{7}{c}{ Months post-infection } \\
\cline { 2 - 8 } & 1 & 2 & 3 & 4 & 5 & 6 & Total \\
\hline AGID- & $72.2 \mathrm{Aab}$ & $88.8 \mathrm{Aa}$ & $83.3 \mathrm{Aab}$ & $72.2 \mathrm{Aab}$ & $50.0 \mathrm{Ab}$ & $59.3 \mathrm{Ab}$ & $70.1 \mathrm{Aab}$ \\
TECPAR & & & & & & & \\
AGID-IPVDF & $83.3 \mathrm{Aa}$ & $77.7 \mathrm{Aa}$ & $61.1 \mathrm{Aa}$ & $72.2 \mathrm{Aa}$ & $61.1 \mathrm{Aa}$ & $62.9 \mathrm{Aa}$ & $69.2 \mathrm{Aa}$ \\
CF & $88.8 \mathrm{Aa}$ & $94.4 \mathrm{Aa}$ & $66.6 \mathrm{Aa}$ & $33.3 \mathrm{Bbc}$ & $33.3 \mathrm{Abc}$ & $22.2 \mathrm{Bc}$ & $53.8 \mathrm{Bb}$ \\
\hline
\end{tabular}

Values followed by distinct lower case letters in the same row differ statistically by Fisher's Exact Test $(\mathrm{P}<0.05)$. Values followed by distinct upper case letters in the same column differ statistically by Fisher's Exact Test $(\mathrm{P}<0.05)$.

Agreement between AGID methods was $86.74 \%$, with a kappa statistics value of 0.734 , confirming a high agreement between the two tests. Conversely, agreement between $\mathrm{CF}$ and both AGID methods was lower, with values of $54.14 \%$ and $54.7 \%$ when CF was compared to the AGID-TECPAR and AGID-IPVDF, respectively. Such lower agreement was confirmed by the kappa statistics values of 0.201 and 0.215 between the CF and AGID-TECPAR or AGID-IPVDF, respectively.

Diagnosis of $B$. ovis infection is based on the association of clinical examination to detect lesions, serological tests, and bacteriology of semen samples from infected rams (Webb et al., 1980; Burguess, 1982). This combined approach is recommended since no single procedure is entirely satisfactory for identification of all 
infected animals in a flock (Lawrence, 1961). The most common clinical sign of $B$. ovis infection is chronic epididymitis in mature rams, which may be absent in most infected animals (Burguess, 1982; Xavier et al., 2009). The occurrence of these asymptomatic infections limits the efficiency of clinical diagnosis. Moreover, shedding of B. ovis in the semen is known to be intermittent and it is usually detectable by bacteriology or polymerase chain reaction (PCR) only after 45 to 60 dpi (Burguess, 1982; Xavier et al., 2010). Therefore, the efficacy of direct methods during the early stages of infection is also considerably limited. The present study demonstrates that antibodies against $B$. ovis in experimentally infected animals are highly detectable by AGID and CF as early as 15 to $60 \mathrm{dpi}$. Consequently, serological methods may be the best alternative for detection of infected animals during the early stages of infection.

It was demonstrated an oscillation in the frequency of rams serologically positive for $B$. ovis by both AGID methods after $75 \mathrm{dpi}$ as well as a constant decrease in the number of positive rams and antibody titers by $\mathrm{CF}$. Additionally, AGID-TECPAR and CF had a statistically significant decrease in sensitivity mainly after the third month of experimental infection. Some experimentally infected rams are able to overcome the infection, which results in absence of detectable antibody titers or bacterial isolation after the acute phase of infection (Burguess, 1982).

Sensitivity of AGID and CF described in this study was lower than those previously described in the literature, which reported sensitivity values over $90 \%$ for these tests (Marín et al., 1989). However, in these previous studies ovine serum samples from naturally infected rams were used, in which case the stage of infection as well as the infectious challenge could not be determined.

In conclusion, both AGID antigens were equally sensitive and specific for the serological diagnosis of $B$. ovis infection in rams, whereas $\mathrm{CF}$ resulted in lower sensitivity after the acute phase of infection. Considering that AGID and $\mathrm{CF}$ were less sensitive after $90 \mathrm{dpi}$, it is recommended that serological diagnosis should be associated to other available diagnostic tests, including bacteriology and PCR for improving the efficiency of the diagnosis of $B$. ovis infection in rams.

Keywords: ram, Brucella ovis, serology, complement fixation, immunodiffusion

\section{RESUMO}

A infecção por Brucella ovis é considerada uma das principais causas de epididimite e infertilidade em carneiros, resultando em falhas reprodutivas e perdas econômicas significativas em rebanhos ovinos ao redor do mundo. O estudo teve o objetivo de avaliar três testes sorológicos disponíveis para o diagnóstico da brucelose ovina por $\mathrm{B}$. ovis, utilizando 181 soros ovinos. Amostras de soro provenientes de carneiros experimentalmente infectados foram coletadas ao longo de 192 dias pós-infecção $(n=117) e$ durante o período pré-infecção (n=9). Adicionalmente, amostras de soro foram obtidas de ovinos provenientes de um rebanho livre para B. ovis $(n=55)$. As técnicas de imunodifusão em gel de agar (IDGA), utilizando dois antígenos disponíveis comercialmente, e de fixação de complemento foram comparadas $(F C)$. Foram obtidos resultados de sensibilidade especificidade semelhantes para ambos os métodos de IDGA e ainda, a técnica de IDGA foi mais eficiente do que a da FC para o diagnóstico sorológico da infecção por B. ovis.

Palavras-chave: ovino, Brucella ovis, sorologia, fixação de complemento, immunodifusão

\section{ACKNOWLEDGEMENTS}

We thank Adriana Amantino M. Martins for technical assistance. MNX, TMAS, EAC, VSM, APL, and RLS are recipients of fellowships from CNPq (Conselho Nacional de Desenvolvimento Científico e Tecnológico). RLS is a fellow of the
John Simon Guggenheim Memorial Foundation. Work in RLS lab is supported by $\mathrm{CNPq}$ and FAPEMIG (Fundação de Amparo a Pesquisa do Estado de Minas Gerais). 


\section{REFERENCES}

ALTON, G.G.; JONES, L.M.; ANGUS, R.D. et al. Techniques for the Brucellosis Laboratory. France: INRA, 1988. 192 p.

BURGUESS, G.W. Ovine contagious epididimytis: a review. Vet. Microbiol., v.7, p.551-575, 1982.

GALL, D.; NIELSEN, K.; VIGLIOCCO, A. et al. Evaluation of an indirect-linked immunoassay for presumptive serodiagnosis of Brucella ovis in sheep. Small Ruminant Res., v.48, p.173-179, 2003 .

HENKEN, A.M.; GRAAT, E.A.M.; CASAL, J. Measurement of disease frequency. In: NOORDHUIZEN, J.P.T.M.; FRANKENA, K.; VAN DER HOOFD, C.M. et al. (Eds.). Application of Quantitative Methods in Veterinary Epidemiology. The Netherlands: Wageningen Pers, 1997. p.63-98.

LAWRENCE, W.E. Ovine brucellosis: a review of the disease in sheep manifested by epididymitis and abortion. Br. Vet. J., v.117, p.435-446, 1961.

MANUAL of diagnostic tests and vaccines for terrestrial animals. Paris: OIE, 2009. 1200p. Disponível em: <http://www.oie.int/eng/normes/mmanual/A_su mmry.htm>. Acessado em: 15 dez. 2009.
MARÍN, C.M.; JIMENES DE BAGUES, M.P.; BLASCO, J.M. et al. Comparison of three serological tests for Brucella ovis infection of rams using different antigenic extracts. Vet. Rec., v.125, p.504-508, 1989.

MOLELLO, J.A.; JENSEN, R.; FLINT, J.C. et al. Placental pathology. I. Placental lesions of sheep experimentally infected with Brucella ovis. Am. J. Vet. Res., v.24, p.897-904, 1963.

MYERS, D.M.; SINIUK, A. Preliminary report on the development of a diffusion-in-gel method for the diagnosis of ram epididymitis. Appl. Microbiol., v.19, p.335-337, 1970.

WEBB, R.F.; QUINN, C.A.; COCKRAM, F.A. et al. Evaluation of procedures for the diagnosis of Brucella ovis infection in rams. Aust. Vet. J., v.56, p. 172-175, 1980.

XAVIER, M.N.; COSTA, E.A.; PAIXÃO, T.A. et al. The genus Brucella and clinical manifestations of brucellosis. Cienc. Rural v.39, p.2252-2260, 2009.

XAVIER, M.N.; SILVA, T.M.A.; COSTA, E.A. et al. Development and evaluation of a speciesspecific PCR assay for detection of Brucella ovis infection in rams. Vet. Microbiol., v.145, p.158164, 2010. 